\title{
REVIEW
}

\section{Endometriosis in Urology - an Update}

\author{
Dan SPINU11,2, Dragoș MARCU11,2, Ovidiu BRATU1,2, Lucian IORGA 1,2, Dan MISCHIANU1,2
}

\begin{abstract}
Introduction: Endometriosis represents the aberrant implantation of endometrial tissue, respectively outside the uterus. It is one of the gynecological diseases with a great impact on the patient's quality of life and especially on the fertility aspects. Due to the aberrant implantation, this disease can theoretically affect any organ in the abdominal and retroperitoneal cavity. Thus, cases involving the organs of the urinary tract are not a surprise.

Material and methods: The present paper focuses on the urological impairment of endometriosis, etiology according to various hypotheses and an update of existing treatment methods. The possible proposals of therapeutic guides found in the literature are also taken into account.Results: The urological condition of this disease seems to increase in frequency in recent years. If in the case of asymptomatic patients an expectant attitude can be approached in relative safety, the local invasive nature of the disease, which can lead to the loss of the function of the various organs of the urinary tract, must not be omitted. In the case of symptomatic patients, the treatment is either hormonal or surgical, lately there is a tendency to combine the two types of treatment. Being a condition with relatively rare urological involvement, the differential diagnosis often omits endometriosis. There are currently several plausible guide proposals, but it takes time and richer casuistry to be able to standardize them. From the point of view of surgical treatment, there is a tendency to introduce robotic surgery in the therapeutic arsenal of this disease, both in the case of classical endometriosis and in the case of urological involvement.
\end{abstract}

Keywords: urinary endometriosis, hormonal therapy, laparoscopic surgery.

\section{Rezumat}

Introducere: Endometrioza reprezintă, conform definiției, implantarea aberantă de țesut endometrial, respectiv în afara uterului. Este una dintre afecțiunile ginecologice cu mare impact asupra calității vieții pacientului și mai ales asupra aspectelor de fertilitate. Din cauza implantării aberante, această boală poate afecta teoretic orice organ de la nivelul cavității abdominale, cât și retroperitoneal. Astfel, cazurile cu implicarea organelor aparatului urinar nu reprezintă o surpriză.Material și metodă: Lucrarea de față se concentrează pe modul în care endometrioza afectează zona urologică, etiologie bazată pe diverse ipoteze și un update al metodelor de tratament existente în prezent. Se au în vedere și eventualele propuneri de ghiduri terapeutice regăsite în literatură. Rezultate: Afectarea urologică a acestei boli pare să crească în frecvență în utimii ani. Dacă în cazul pacientelor asimptomatice o atitudine bazată pe expectativă poate fi abordată în relativă siguranță, nu trebuie omis caracterul invaziv local al afectiunii care poate duce la pierderea funcției diferitelor organe ale aparatului urinar. În cazul pacienților simptomatici, tratamentul este fie hormonal, fie chirurgical, în ultima vreme apărând o tendință de a combina cele două tipuri de tratament. Fiind o afectiune cu implicare urologică relativ rară, de multe ori diagnosticul diferențial omite endometrioza. Există în prezent mai multe propuneri de ghiduri plauzibile, dar este nevoie de timp și de o cazuistică mai bogată pentru a le putea standardiza. Din punct de vedere al tratamentului chirurgical, există tendința de a introduce chirurgia robotică în arsenalul terapeutic al acestei boli, atât în cazul endometriozei clasice cât și în cazul implicării urologice.

Cuvinte cheie: endometrioza urinară, terapie hormonală, chirurgie laparoscopică.

${ }^{1}$ Clinic of Urology, "Dr. Carol Davila" Central Military Emergency University Hospital, Bucharest, Romania

$23^{\text {rd }}$ Clinical Department, "Carol Davila" University of Medicine and Pharmacy, Bucharest, Romania

\section{Corresponding author:}

Dan SPINU, Clinic of Urology, „Dr. Carol Davila”

Central Military Emergency University Hospital,

Bucharest, Romania.

E-mail:dan.spinu@yahoo.co.uk 


\section{INTRODUCTION}

Endometriosis is a benign gynecological condition with a frequency that varies between $5 \%$ and $15 \%$ among women. The classifications are multiple depending on the targets, the most used include a combination of anatomical site and tissue penetration. Thus we have ovarian endometriosis, superficial and infiltrative peritoneal. A rare type of endometriosis called intramiometrial endometriosis or adenomyosis involves the penetration of the uterine muscle wall by endometrial tissue following various surgeries with a proportional increase in the risk of placenta accreta. The biggest therapeutic problems involve the infiltrative endometriosis that can penetrate up to about $5 \mathrm{~mm}$ or more into the depth of the wall of the affected organ.

The frequency of urinary tract endometriosis is rising in recent years, with figures ranging from $0.3 \%$ to $12 \%{ }^{1,2,3,4}$. The bladder is $80 \%$ affected followed by the ureter in $14 \%$ of cases and kidneys. in $4 \%$ of cases ${ }^{5}$. A particular aspect of infiltrative endometriosis is the relatively frequent involvement of the lower urinary tract.

Endometriosis is the prerogative of women of reproductive age. Endometriosis decreases in frequency with the onset of menopause, probably due to the disappearance of sex hormones. Premenopausal and post menopausal endometriosis is very rare and only a few cases have been documented in the literature. The information regarding the evolution of endometrial lesions during pregnancy is contradictory.

In terms of etiology, endometriosis can be primary or secondary. The primary one is manifested by the appearance of endometriotic foci without an obvious causal explanation. The secondary one is manifested after various surgeries at the pelvis. More than 50\% of cases of bladder and ureteral endometriosis occur in women who have undergone various gynecological surgeries.

There are multiple theories that have tried to explain the occurrence of this type of disease: the embryonic theory that advocates the origin of endometriosis in the existence of remnants of the Muller canal, the theory of iatrogenicity that explains the disease after inoculation during surgery, the theory of migration during menstruation with aberrant implantation of endometrial cells and last but not least the most widely accepted theory of endometrial cell transplantation in various organs via lymphatic or blood circulation ${ }^{6,7,8,9}$.

\section{MATERIAL SI METHODS}

This paper focuses on the urological impairment of endometriosis, on various therapeutic methods, both surgical and medical. The proposals for therapeutic guidelines found in various papers are reviewed with emphasis on new therapeutic methods already confirmed or being standardized. The vast majority of the works found are case presentations due to the rarity of urological involvement, with very few materials aimed at an attempt to standardize treatment.

\section{RESULTS}

This type of pathology is rare, most of the available materials being case presentations. The few articles that contain groups of patients mostly focus on affecting one of the organs of the urinary tract. Our approach aims at a stratification according to the interested organ. There are also materials that generally treat endometriosis of the urinary tract.

\section{BLADDER ENDOMETRIOSIS}

This type of impairment was first described in 1921 by Judd, later by Clement and Young in 1992 ${ }^{10,11}$.

The most affected area of the bladder is the trigone and dome, being the closest to the uterus. One third of patients remain asymptomatic, especially when the size of the endometriotic areas does not exceed $2 \mathrm{~cm}$. When the disease becomes symptomatic, dysuria, urinary urgency, painful urination, burning sensation when urinating and discomfort in the small pelvis appear. These symptoms are repetitive and overlap with the onset of the menstrual cycle. Although hematuria is the symptom that makes the patient go to the doctor most often its frequency does not exceed 20\%. Hematuria occurs in the case of erosion of the entire detrusor muscle layer with the appearance of endometriotic tissue at the endovesical level and bleeding, which is quite rare ${ }^{12}$.

As with endometriosis in general, bladder endometriosis may be primary, occurring spontaneously in approximately $11 \%$ of patients with urinary and secondary endometriosis after surgery on the small pelvis, and approximately $50 \%$ of patients with bladder endometriosis with secondary endometriosis ${ }^{13}$.

The differential diagnosis poses big problems in these patients, there are many pathologies that overlap as symptoms: cystitis, overactive bladder, various neo- 
plasms of the small pelvis, pelvic pain syndrome that includes many neurological causes, interstitial cystitis. There are also cases in which hematuria overlaps on a bladder endometriosis transformed into adenocarcinoma ${ }^{14}$.

Although the peak incidence of urinary tract endometriosis, bladder endometriosis is a rare condition, with older reports citing approximately 350 cases worldwide ${ }^{15}$.

The investigations start from the clinical examination, the vaginal examination being very important in detecting various nodular formations in the bladder wall. Urine tests can detect the presence of microscopic hematuria that may go unnoticed, in some cases the existence of anemia installed over time and therefore well tolerated by the body can be detected. Urinary cytology does not give much information in general. Renal function should be evaluated in advance given the possibility of loss of unilateral renal function over time, which often goes unnoticed.

The basis of the diagnosis remains the imaging protocol, the ultrasound with three approaches: abdominal, transvaginal and transrectal being the starting point. The specificity of a well-done ultrasound can reach $100 \%$. The limit of the ultrasound is represented by the lesions with dimensions smaller than $3 \mathrm{~cm}$, in this case the specificity decreasing up to $50 \%$. Contrast-enhanced pelvic MRI is currently considered the "gold standard" diagnostis for endometriosis. Especially 3 Tesla MRI is considered the optimal investigation in preoperative endometriosis in order to create a map of the lesions. It is worth mentioning the MRI approach as standard for bladder endometriosis.

In recent years Doppler ultrasound has gained more and more ground, in a comparison between cystoscopy and MRI Doppler ultrasound has had better results than cystoscopy and at least equivalent to MRI examination ${ }^{16}$.

Cystocopy, although it remained last in the list of investigations, is one of the procedures that has kept its value over time. It can specify the location of the formation, if it has penetrated to the level of the bladder mucosa, if it infiltrates it, if it catches or not the ureteral orifices. The lesions often appear as nodular masses of various sizes, solitary or multiple, of various colors: blue-red, blue-black or blue-brown are the most common combinations. Great attention must be paid to the distance between the lesions and the ureteral orifices, most often lesions located less than $2 \mathrm{~cm}$ from the ure- teral ostium require ureteral reimplantation. Cystocopy followed by transurethral bioptic resection remains fundamental in the diagnosis and treatment of bladder endometriosis.

The treatment of this condition is a challenge for both gynecologists and urologists. Due to its expansive nature and the frequent appearance of recurrences, it borrows from the character of neoplasms even if it is recognized as a benign disease.

There is currently no recognized guide for the treatment of endometriosis in general and urinary tract in this case due to the rarity of the disease and especially the lack of randomized trials. There are many factors that must be taken into account in the case of this disease: the patient's age, its fertility stage, the extent of the disease locally and / or in other organs and last but not least the severity of the symptoms.

There are two main treatment directions: pharmacological and surgical. There is often a tendency to combine them for a synergistic effect.

The pharmacological approach consists of GNRH agonists and antagonists, progestogens and combined oral contraceptive therapy. The goal of this type of treatment is to obtain regression of endometrial tissue by inducing a false menopausal status. Unfortunately, in the case of infiltrative endometriosis, more than $50 \%$ of patients do not respond to treatment.

Pharmacotherapy gets a good response in the vast majority of cases as long as it is administered. Many cases treated strictly pharmacologically showed relapse immediately after stopping the medication. According to Westney et al., lesions smaller than $5 \mathrm{~mm}$ are ideal for this type of treatment, achieving a complete resolution 18 months after starting treatment in 12 of 14 patients ${ }^{17}$.

An alternative to systemic hormone treatment that has many side effects that are difficult to tolerate has emerged in recent years in the form of intrauterine devices with prolonged release of medication locally. Thus with this type of treatment the systemic effects are avoided at least partially and the fertility is preserved which is very important in the case of young patients. A prospective study in a group of 334 patients who received an intrauterine device with levonorgestrel reported a cure rate of $30.8 \%$ in patients with endometriosis $^{18}$.

In conclusion, the role of pharmacological treatment is more adjuvant, leaving room for surgical treatment which is still the standard in this disease. 
Surgical treatment includes a plethora of approaches starting with the endoscopic approach, laparotomy with endometriotic tissue resection, the laparoscopic approach which is currently the ,gold standard" and lately robotic surgery seems to find a place in the therapeutic arsenal of this disease.

Unlike gynecological surgery, endometriosis of the urinary tract also benefits from the endoscopic aspects of surgical treatment - TUR-V endovesical transurethrosection of the tumor.

In the case of bladder endometriosis, TUR-V can be performed, partial cystectomy if the lesion is voluminous, a combination of TUR and laparoscopic or robotic approach. At present, the combination between laparoscopy and endoscopy is the one that gives the best results with the minimum of complications ${ }^{19,20}$. "JJ" stent insertion is mandatory in the case of lesions in the vicinity of the ureteral orifices both for the safety of the ureters and for the intraoperative guidance of the surgeon.

Nezhat et al presented their experience in robotic-assisted laparoscopic surgery with good results. The advantage of the procedure is related to a better suturing technique and a higher precision of the instrument movements, but it also has the disadvantage of a longer time of preoperative preparation and the financial aspect $^{21}$.

The most serious problem that surgeons face in treating this condition is recurrence. The purpose of surgery of any kind is the eradication of endometrial tissue outside the uterus. In the case of endourology, the resection can be performed as long as the bladder wall allows, beyond it appears the rupture of the bladder with the appearance of fluid overflow either pro or intra peritoneal. Fedele et al showed that the major risk factor for recurrence is the patient's age. The explanation is obviously the hormonal status, which corroborated with the patient's age puts the surgeon in quite delicate situations: on the one hand the complete eradication of the disease is considered, on the other hand the fertility aspect must be taken into account ${ }^{22}$.

\section{URETERAL ENDOMETRIOSIS}

It is the second most common site of this type of disease. The first case was reported in 1917 by Cullen. Unlike bladder endometriosis, there seems to be a greater concern for this anatomical area, there are several systematized articles related to this pathology.
It can be divided into 2 types extrinsic and intrinsic with the extrinsic gathering more than $80 \%$ of cases, the intrinsic being a relatively rare pathology and based on the primary type of endometriosis. The most affected area is the pelvic ureter and especially the one on the left side. Bilateral involvement is rare in between $10 \%$ and $20 \%$ of $\operatorname{cases}^{23,24}$. The most intriguing aspect is that the two types of endometriosis can coexist in the same patient, moreover this type of division is based strictly on the final pathological examination.

The clinic of ureteral involvement is very elusive and is based more on indirect information. Most often the gynecological endometriotic symptomatology is the one that raises the question marks, while repetitive renal colic superimposed on menstruation is rare and more than $50 \%$ of patients are asymptomatic ${ }^{25}$. Due to the slow installation of the obstruction, this group of patients often ends up losing kidney function on one or both sides.

The paraclinical imaging are in this case of limited value, not being able to specify the necessary pre-operative information. Relatively recently Sillou et al have shown that MRI examination especially in ureteral damage can provide accurate information about the extent and location of endometriosis areas. They were able to do this by comparing the MRI result with the intraoperative results ${ }^{26}$. Moreover, they tried based on imaging studies to differentiate extrinsic endometriosis from intrinsic endometriosis with promising results.

We must not forget the other methods of imaging investigation starting with ultrasound which is mandatory in the follow-up of patients with endometriosis. CT examination, urography, uro-CT did not prove their superiority over MRI.

None of the imaging investigation methods is infallible, so the histopathological examination is the one that decides the diagnosis. In the case of intrinsic endometriosis, ureteroscopy with biopsy of the formation remains the elective method in diagnosing this pathology. Moreover, it allows the ablation of the formation in the case of minimally invasive surgical treatment ${ }^{27}$.

The treatment benefits from a higher degree of personalization compared to bladder endometriosis. Hormone treatment has much more limited indications, having reduced efficiency on the ureteral obstruction. Only in carefully selected cases of young patients who want to procreate hormone treatment can have a limited indication and then subject to periodic ultrasound checks. The major difference is that at the ureteral level after each episode of bleeding there is a process of local 
fibrosis that responds only little or not at all to hormonal treatment. There is still much discussion regarding postoperative adjuvant hormone therapy.

Surgical treatment consists of various segmental resection techniques with urinary tract restoration: segmental ureterotomies with end-to-end anastomosis, segmental ureterectomy with ureteroneocystostomy, various uretero-bladder augmentation procedures (Boari Flap, Psoas Hitch, Lich-Gregoire, Leadbetter-Leadbetter). In rare cases, nephroureterectomy can also occur if we are dealing with a kidney with a scintigraphic activity of up to $15 \%{ }^{29}$.

Endourology, with laser resection of intraluminal lesions, offers good results but with a high recurrence rate reaching up to $30 \%$.

In addition to ablative surgery, ureterolysis is very popular, which consists in resecting the lesions without changing the integrity of the urinary tract.

All these procedures can be performed classically, laparoscopically or more recently robotically. At the moment, whether we are talking about ablative surgery or ureterolysis, the laparoscopic approach is the "gold standard".

There are multiple discussions regarding the type of intervention used. Some authors such as Bosev et al recommend ureterolysis as the treatment of choice for patients with medium and low grade ureterohydronephrosis ${ }^{28}$. Other authors believe that ureterolysis is effective in areas of endometriotic tissue smaller than 3 $\mathrm{cm}^{30}$. As a procedure, ureterolysis is contraindicated in the case of intraluminal endometriosis due to the high rate of postoperative recurrence. Many authors who supported ureterolysis have concluded that there are still cases that cannot be addressed in this way ${ }^{31}$.

However, the current trend is to approach this $\mathrm{pa}^{-}$ thology as conservatively as possible from a surgical point of view. Numerous relatively recent studies support the superiority of ureterolysis over classical ablative surgery ${ }^{32,33}$.

Mainly, ureterolysis currently addresses lesions smaller than $3 \mathrm{~cm}$, without ureterohydronephrosis, in the proximal or distal ureter, while ablative and reconstructive surgery addresses lesions larger than $3 \mathrm{~cm}$, with associated ureterohydronephrosis associated with the pelvic ureteral level.

There have been and still are many discussions about stenting the affected ureter with the "JJ" probe. Easy guidance during the operation, easy detection of the ureter and avoid injury to it are arguments in fa- vor of using the stent while increasing stiffness of the ureter and increasing the difficulty of ureterolysis are arguments against its use. In addition, it can be a real help for endoprosthesis of the ureter in case of an intraoperative injury.

Surgical procedures play a very important role in the case of ureteral endometriosis, while hormone therapy has a more adjuvant role with limited indications as a primary treatment.

However, despite aggressive surgical treatment in $40 \%$ of cases the kidney function of the affected kidney is $\operatorname{lost}^{34}$.

\section{RENAL ENDOMETRIOSIS}

Represents the rarest of all, summarizing along with urethral involvment less than $5 \%$ of cases $^{35}$. The clinical picture is completely nonspecific, the most common symptom being lumbar pain mimicking nephralgia. Hematuria is rarely present and often the disease can evolve silently for a long time being an accidental discovery.

In the few published cases the treatment consisted of nephrectomy mainly due to the suspicion of neoplasia or due to a functionally compromised organ. The histopathological exam is the one that decides the diagnosis.

There are cases in which the endometrial formation does not compromise the kidney, in these cases an ultrasound-guided kidney biopsy may be sufficient to decide a histopathological diagnosis without resorting to ablative surgery ${ }^{36}$.

We must not forget the aggressive expansive nature of endometriosis and the possibility that at the time of diagnosis the kidney may be compromised. Open, laparoscopic or robotic conservative surgery can also be used successfully in renal endometrial involvement ${ }^{37}$.

\section{DISCUSSIONS}

Endometriosis is a general health problem. If gynecologically it has a significant impact on fertility, from the urologic point of view it can lead to compromise of one or even both kidneys. Endometriosis of the urinary tract is a rare pathology, due to its rarity; we cannot talk about treatment guidelines. In addition, being a rare pathology, it is often omitted in the differential diagnosis with other diseases.

Hormone treatment addresses to a small segment of patients, especially those targeting fertility. There are 
reports of the use of hormone medication as an adjuvant therapy, but there is still no standardized protocol in this regard. In addition, the side effects of hormonal medication are significant, which encourages the patient to adress the surgical approach.

Surgical treatment remains the basic approach to this condition. There are currently no unanimously accepted guidelines regarding urinary tract endometriosis but certain treatment principles have emerged. If in the case of the bladder the hormonal treatment can be used with a relatively large safety margin in the case of ureteral endometriosis, this type of treatment has limited indications. Ablative surgery and ureterolysis are used with similar success but for different anatomical areas and the evolutionary stage of the disease. Open surgery, laparoscopy, endoscopy in the case of ureteral intraluminal endometriosis and more recently robotic

\section{References}

1. Collinet P, Marcelli F, Villers A, et al. Management of endometriosis of the urinary tract. Gynecol Obstet Fertil. 2006;34:347-52.

2. Cullen TS: Adenomyoma of the recto-vaginal septum. Bull Johns Hopkins Hosp 1917;28:343-349.

3. Yohannes P. Ureteral endometriosis. J Urol. 2003;170:20-5.

4. Razzaghi MR, Rahjoo T, Golshan A. Endometriosis with pure urinary symptoms. Urol J. 2009;6:132-4.

5. Comiter CV. Endometriosis of the urinary tract. Urol Clin North Am. 2002;29:625-35

6. Donnez J, Van Langendonckt A, Casanas- Roux F, et al. Current thinking on the pathogenesis of endometriosis. Gynecol Obstet Invest. 2002;54 Suppl 1:52-8.

7. Somigliana E, Vercellini P, Gattei U, Chopin N, Chiodo I, Chapron C. Bladder endometriosis: getting closer and closer to the unifying metastatic hypothesis. Fertil Steril. 2007;87:1287-90.

8. Vercellini P, Busacca M, Aimi G, Bianchi S, Frontino G, Crosignani PG. Lateral distribution of recurrent ovarian endometriotic cysts. Fertil Steril. 2002;77:848-9.

9. Vercellini P, Frontino G, Pisacreta A, De Giorgi O, Cattaneo M, Crosignani PG. The pathogenesis of bladder detrusor endometriosis. Am J Obstet Gynecol. 2002;187:538-42.

10. E. S. Judd, "Adenomyomata presenting as a tumour of the bladder," Surgical Clinics of North America, vol. 1, pp. 1271-1278, 1921.

11. P. B. Clement and R. H. Young, "Endocervicosis the bladder. A report of six cases of a benign m"ullerian lesion that may mimic adenocarcinoma," The American Journal of Surgical Pathology, vol. 16, no. 6, pp. 533-542, 1992.

12. Fauconnier A, Chapron C, Dubuisson JB, Vieira M, Dousset $B$, Breart G. Relation between pain symptoms and the anatomic location of deep infiltrating endometriosis. Fertil Steril. 2002; 78:719-26

13. Comiter CV: Endometriosis of the urinary tract. Urol Clin North Am 2002; 29: 625-635. surgery represent multiple possibilities to approach this pathology. The main problem of this disease is recurrence, patients with this disease requiring careful monitoring at least until the onset of menopause. Even if the technical possibilities in the form of robotic surgery have evolved, the treatment principles of this pathology have remained largely unchanged. There is a tendency towards standardization of therapeutic procedures and indications.

Compliance with ethics requirements: The authors declare no conflict of interest regarding this article. The authors declare that all the procedures and experiments of this study respect the ethical standards in the Helsinki Declaration of 1975, as revised in 2008(5), as well as the national law. Informed consent was obtained from all the patients included in the study.

14. Allen D, O'Brien T, Pingle P, Chandra A: Endometrioid adenocarcinoma of the bladder. Histopathology 2005; 46: 232-233.

15. J. Donnez, F. Spada, J. Squifflet, and M. Nisolle, "Bladder endometriosis must be considered as bladder adenomyosis," Fertility and Sterility, vol. 74, no. 6, pp. 1175-1181, 2000.

16. Thonnon C, Philip CA, Fassi-Fehri H, et al. Three-dimensional ultrasound in the management of bladder endometriosis. J Minim Invasive Gynecol. 2015;22:403-9.

17. Westney OL, Amundsen CL, McGuire EJ: Bladder endometriosis: conservative management. J Urol 2000; 163: 1814-1817.

18. M. Canis, J. G. Donnez, D. S. Guzick et al., "Revised American Society for Reproductive Medicine classification of endometriosis: 1996," Fertility and Sterility, vol. 67, no. 5, pp. 817-821, 1997.

19. Nupur Tamhane 1, Lucas Wiegand 2, Emad Mikhail, Robotic excision of deep infi Itrating endometriosis at the uretero-vesical junction - Int Braz J Urol. Vol. 46 (1): 140-140, January - February, 2020

20. P.A. Bolze, P. Paparel, F. Golfier, [Urinary tract involvement by endometriosis. Techniques and outcomes of surgical management: CNGOF-HAS Endometriosis Guidelines], Gynecologie, obstetrique, fertilite \& senologie 46 (3) (2018) 301-308.

21. Nezhat C, Hajhosseini B, King LP. Robotic-assisted laparoscopic treatment of bowel, bladder, and ureteral endometriosis. JSLS. 2011;15:387-92

22. Fedele L, Bianchi S, Zanconato G, Raffaelli R, Berlanda N: Is rectovaginal endometriosisa progressive disease? Am J Obstet Gynecol 2004; 191: 1539-1542.

23. Blaustein's Pathology of The Female Genital Tract. 5th ed., Springer- Verlag, New York, 2002. p 1193-1247.

24. Karadag MA, Aydin T, Karadag OI, et al. Endometriosis presenting with right side hydroureteronephrosis only: a case report. J Med Case Rep. 2014;8:420

25. Seracchioli R, Mabrouk M, Montanari G, Manuzzi L, Concetti S, Venturoli S. Conservative laparoscopic management of urinary 
tract endometriosis (UTE): surgical outcome and long-term follow-up. Fertil Steril. 2010;94:856-61.

26. Sillou S, Poiree S, Millischer AE, Chapron C, Helenon O. Urinary endometriosis: MR Imaging appearance with surgical and histological correlations. Diagn Interv Imaging. 2015;96:373-81.

27. Castaneda CV, Shapiro EY, Ahn JJ, et al. Endoscopic management of intraluminal ureteral endometriosis. Urology. 2013;82:307- 12.

28. Bosev D, Nicoll LM, Bhagan L, et al: Laparoscopic Management of Ure- teral Endometriosis: The Stanford University Hospital Experience With 96 Consecutive Cases. J Urol. 2009;182:2748-2752.

29. F. Barra, C. Scala, E. Biscaldi et al., "Ureteral endometriosis: a systematic review of epidemiology, pathogenesis, diagnosis, treatment, risk of malignant transformation and fertility," Human Reproduction Update, vol. 24, no. 6, pp. 710-730, 2018.

30. Mu D, Li X, Zhou G, Guo H. Diagnosis and treatment of ureteral endometriosis: study of 23 cases. Urol J. 2014:11:1806-12.

31. Antonelli A, Simeone C, Zani D, Sacconi T, Minini G, Canossi E, et al. Clinical aspects and surgical treatment of urinary tract endometriosis: our experience with 31 cases. Eur Urol 2006;49:1093-7.

32. Ghezzi F, Cromi A, Bergamini V, Serati M, Sacco A, Meuller MD. Outcome of laparoscopic ureterolysis for ureteral endometriosis. Fertil Steril 2006;86:418-22.
33. Soriano D, Schonman R, Nadu A, Lebovitz O, Schiff E, Seidman DS, et al. Multidisciplinary team approach to management of severe endometriosis affecting the ureter: long-term outcome data and treatment algorithm. J Minim Invasive Gynecol 2011;18:483-8.

34. Maccagnano C, Pellucchi F, Rocchini L, Ghezzi M, Scattoni V, Montorsi F, et al. Ureteral endometriosis: Proposal for a diagnostic and therapeutic algorithm with a review of the literature. Urol Int. 2013;91:1-9. [PubMed] [Google Scholar]

35. Cheng $\mathrm{C}-\mathrm{H}$, Kuo H-C, Su B. Endometriosis in a kidney with focal xanthogranulomatous pyelonephritis and a perinephric abscess. BMC Res Notes 2015;8:591.

36. Gupta K, Rajwanshi A, Srinivasan R. Endometriosis of the kidney: Diagnosis by fine-needle aspiration cytology. Diagn Cytopathol 2005;33:60-61.

37. Anand V. Badri, Rachel Jennings, Pavan Patel, and Daniel D. Eun, Renal Endometriosis: The Case of an Endometrial Implant Mimicking a Renal Mass, Journal of Endourology Case Reports, vol 4.1, Pp. 176-178, 2018 